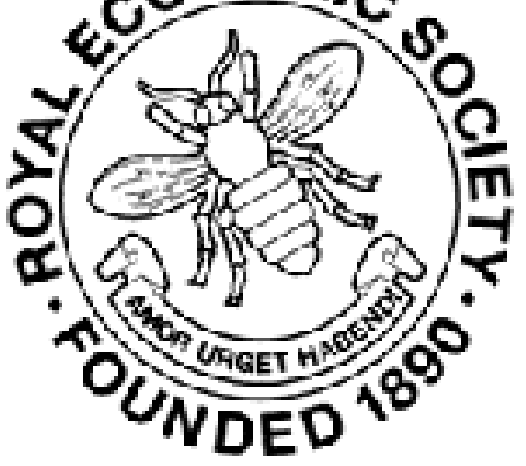

The Financial Relations Between English Localities

Author(s): Edwin Cannan

Source: The Economic Journal, Vol. 13, No. 49 (Mar., 1903), pp. 6-19

Published by: Wiley on behalf of the Royal Economic Society

Stable URL: http://www.jstor.org/stable/2956863

Accessed: 25-06-2016 17:12 UTC

Your use of the JSTOR archive indicates your acceptance of the Terms \& Conditions of Use, available at

http://about.jstor.org/terms

JSTOR is a not-for-profit service that helps scholars, researchers, and students discover, use, and build upon a wide range of content in a trusted digital archive. We use information technology and tools to increase productivity and facilitate new forms of scholarship. For more information about JSTOR, please contact support@jstor.org.

Royal Economic Society, Wiley are collaborating with JSTOR to digitize, preserve and extend access to The Economic Journal 


\section{THE FINANCIAL RELATIONS BETWEEN ENGLISH LOCALITIES ${ }^{1}$}

IN the discussion of the real or imaginary grievances of ratepayers and of schemes for further relieving local rates on property by contributions from the national taxes on consumption or income, it is usual to ignore altogether the complicated financial relations created by the Local Government Act of 1888 between the various local authorities and areas. The reason is not that these relationships are felt to be satisfactory, but simply that scarcely anyone even imagines he understands them well enough to be able to make any statement whatever about them. As a matter of fact most of them are so absurd that if they were generally understood they could not long be tolerated, even by that patient mother of abuses, the British Parliament. I propose therefore to state what they are, and explain their actual effects upon the rates levied within the different areas.

The first financial relation with which we have to deal arises from the fact that in each administrative county the noncounty boroughs, the urban districts, and the rural districts can claim certain subsidies from the county as follows:-

(1) Each non-county borough and each urban and rural district can claim half the salaries of medical officers and inspectors of nuisances when the conditions of their appointment are approved by the Local Government Board.

1 This article contains the substance of a Warburton Lecture delivered at Owens College, Manchester, on November 26th, 1902. The chief authorities used are the Annual Local Taxation Returns for 1899-1900, and the Local Taxation (England) Account for 1899-1900. It should be understood, however, that not one of the rates in the pound given are to be found in these or any other authorities. They have been worked out from the totals by the writer, and he cannot hope that so large a number of arithmetical operations have been performed entirely without error. Moreover, the figures relate only to a single year, and therefore sometimes do not represent a fair average, as the payments are sometimes delayed owing to disputes or other causes. Attention should therefore be given to the genera result rather than to individual cases. 
(2) Each non-county borough and urban district can claim the whole amount expended by them on main roads, including the footways. ${ }^{1}$

(3) Each non-county borough which has a police force of its own can claim half the pay and half the cost of the clothing of the police.

The first of these claims is not directly of any great financial importance since it amounts to a bare $\$ 100,000$ for all England and Wales outside London. But almost the first requisite of sound public finance is simplicity, and it may therefore be laid down as a general principle that the law should not require one authority to make to another trumpery payments which merely encumber and confuse the accounts without making any perceptible difference to the rates. The spreading of half the salaries of medical officers and sanitary inspectors over the whole county will never make any perceptible difference to the rates of the locality, and therefore should not be required even if the redistribution of burden effected were desirable in itself. But no one has contended that the redistribution is desirable in itself. It exists simply in order to give the Local Government Board a certain control over the appointment of the officers, a thing which is extremely undesirable in itself, and which, if it were desirable, might easily be secured by some less illogical method than making a third party pay half the salaries.

The payment for the cost of urban main roads is much more considerable. In the aggregate it amounted to $£ 706,870$. in 1899-1900. ${ }^{2}$ If we take the urban districts on the one hand, and the rural districts on the other in the aggregate, we find that the fact that they are in partnership in regard to the main roads does not make any considerable difference. The total cost of all the main roads, urban and rural, outside the county boroughs is nearly $5 d$. in the $\mathscr{E}$, and if the urban districts paid only for the urban main roads and the rural districts only for the rural main roads, the urban districts would pay about $4 \frac{1}{4} d$. in the $£$ and the rural nearly $5 \frac{1}{4} d$. But the difference which the partnership makes to individual urban districts is enormous; some urban districts get nothing at all and others get over $2 s$. in the $\&$. In Table I. I have endeavoured to show roughly how the partnership affects

1 Main roads, whether urban or rural, are a county charge, but the Local Government Act allowed the urban districts to retain their management, irrespective of the wishes of the county, while the rural districts were only allowed to retain the management by agreement with the county, and therefore under its control.

2 Annual Local Taxation Returns, Pt. v. pp. 114 and 224. 
the non-county boroughs and urban districts of Lancashire. The local taxation returns unfortunately do not now give the payments from the county to urban districts for medical officers' and inspectors' salaries separately from the main road payments, so that I have been obliged to take both sums together in the table, but it may be very safely assumed that the main road payment is the dominating factor:-

\section{TABLe I.}

Amount in the $£$ of rateable value received from the administrative county by Lancashire urban districts, including boroughs, in 18991900 .

(1) Under $3 d$. in the $£:-$

Ashton-under-Lyne, Blackpool, Carnforth, Fleetwood, Gorton, Grange, Gt. Crosby, Hurst, Lancaster, Levenshulme, Litherland, Lytham, Morecambe, Moss Side, Much Woolton, Reddish, St. Anne's, Southport, Urmston, Warrington, Waterloo, Widnes, Withington.

(2) $3 d$. and under $6 d .:-$

Abram, Accrington, Allerton, Ashton in Makerfield, Aspull, Atherton, Barrowford, Brierfield, Chorley, Church, Darwen, Droylsden, Eccles, Farnworth, Garston, Golborne, Great Harwood, Heaton Norris, Horwich, Kirkham, Lees, Leyland, Little Woolton, Longridge, Nelson, Newton in Makerfield, Oswaldtwistle, Pemberton, Prescot, Royton, Skelmersdale, Stretford, Trawden, Tyldesley, Ulverston, Wardle.

(3) $6 d$. and under $9 d .-$

Billinge, Castleton, Chadderton, Colne, Crompton, Croston, Dalton, Failsworth, Haydock, Huyton with Roby, Ince in Makerfield, Kearsley, Little Hulton, Mossley, Rawtenstall, Padiham, Whitworth.

(4) $9 d$. and over:-

Adlington, Audenshaw, Bacup, Blackrod, Clayton, Denton, Fulwood, Heywood, Hindley, Irlam, Lathom, Little Crosby, Little Lever, Littleborough, Middleton, Milnrow, Norden, Orrell, Ormskirk, Prestwich, Radcliffe, Rainford, Ramsbottom, Rishton, Standish, Swinton, Turton, Upholland, Walton-ledale, Westhoughton, Whitefield, Withnell, Worsley.

Looking at the list we see in the first place that towns on the coast get but little; nearly all the coast towns in Lancashire are in the " under $3 d$. ." list. The reason is, of course, that main roads do not run into the sea, and so a town on the coast, especially if the coast is convex in shape like an important part of the Lancashire coast, has less chance of having a large 
mileage of main roads than an inland town. Secondly, we may notice that urban districts which are populous suburbs of the great towns appear to come off somewhat poorly; this is clearly because a suburb is not likely to have more than one main road, whereas an independent market town of equal population is likely to have two or three main roads crossing each other in its centre.

The present arrangement under which the whole county pays the piper, while each urban district council calls the tune, is obviously open to serious objection. Human nature being what it is, the arrangement necessarily encourages extravagant expenditure on the urban main roads and suggests semi-fraudulent measures for making the main road account bear as large a proportion as possible of the general cost of road maintenance in the district. In spite of the present and the much-prophesied future growth of long distance road traffic it remains true, and is likely long to do so, that the condition of the high street of even a small town is in ordinary cases of much greater importance to the inhabitants of the town than to the rest of the county. No doubt the passing cyclist or automobilist, still heartily cursing the county borough council of Preston, is delighted when he arrives on the wood paving of Penny Street in the non-county borough of Lancaster, but the through traffic in Penny Street may be safely said to be not a thousandth part of the local traffic, and even in quite small towns it is a trifling proportion. Moreover, in one important respect, that of noise, the condition of the road is of more interest to the occupiers of property abutting upon it than to the users of the road itself. So far as the side walks are concerned, it seems absurd to spread the charge beyond a small area; is it not ridiculous to rate a person living in Withington, on the south side of Manchester, for footpaths in Dalton in Furness where he has never been in his life? 'If one place is content with gravel, and another wants limmer asphalt, there is no reason why the first should not be allowed the saving and the second the luxury. Probably the legislature never thought of footpaths, but the courts have held that it must have meant to include them.

It would appear easy enough to get rid of the whole system by simply exempting the urban districts from being rated towards the county's expenses on main roads and at the same time abolishing the county's liability for urban main roads, the county of course, retaining power to make grants in aid (from rates levied over the whole county) to the few urban districts which 
have important main roads in which their own interest is not overwhelming. If it was thought that the counties could not be trusted to make such grants fairly, it might perhaps be arranged that each urban district should have a definite sum per mile of main road, the sum to be based on the average cost of rural roads in the county and the total required for the grant to' be levied by rate from the urban districts generally.

The payments from the counties towards the expenses of police under the control of non-county boroughs is not very large; it was only £94,055 for all England and Wales in 1899-1900. It only concerns 40 counties and 69 boroughs at present, and it is more likely to diminish than to increase, since few fresh non-county borough police-forces now come into existence, and the present number is reduced whenever one of the boroughs rises to the rank of county-borough. The arrangement is equally curious and absurd. Half, not of the whole police expenses, but only of those incurred in paying and clothing the police, is pooled between the administrative county and the non-county police boroughs, so that increases and decreases fall upon the general county rate levied from the whole administrative county, including the non-county police boroughs. The remainder of the cost of each particular police force is borne by the particular area policed; so, for example, if Dover builds a palatial police station, only Dover rates will suffer, but if Dover adopts an extravagant uniform, all Kent up to Gravesend (another police borough) will have to contribute towards one-half of the cost.

The general effect of the payment is to favour the police boroughs. Half the cost of pay and clothing in the administrative counties and non-county police boroughs taken together was in $1899-1900, £ 642,606$-almost exactly $1 \frac{1}{2} d$. in the pound of rateable value, while the corresponding cost of the police boroughs is $£ 94,055$ - or a little over $2 \frac{3}{4} d$. in the pound. On the average under present conditions the payment raises the rates of the administrative counties outside the police boroughs by about one twelfth of a penny and diminishes those of the police boroughs by about $1 \frac{1}{4} d$. There is no wide deviation from the average. In 1899-1900 the receipts of the boroughs were all between $2 d$. and $4 d$. in the pound. So that if this financial relation were abolished and the county on the one hand and the police boroughs on the other were each left to raise the whole cost of their police by rates on their own area, it would make very little difference; most of the police borough rates would rise about a penny in the pound and 
some might rise $2 d$. in the pound, but that would be all, even if expenditure were not reduced, as it probably would be.

The utility of the present arrangement appears to be absolutely nil. As the payment to the boroughs is contingent on the approval of the police force by the Home Secretary, it gives the central bureaucracy a certain control over the management, and this is often held up as an advantage. But exactly as much control could be secured to the central government by naking a borough which does not maintain an efficient police force liable to some other considerable fine or deduction. To make the fine vary as it does now with the cost of police is absurd, since the more inadequate the police force the less will the fine be. A borough which boldly maintained less than half the police deemed requisite by the Home Office inspector would gain by it. Against the very doubtful advantage of central control there are two disadvantages (1) the loss of simplicity of accounts; (2) the encouragement of extravagance invariably occasioned by half grants. The old grants from the State were discontinued because of this disadvantage in 1888 ; its economic basis is pointed out by Prof. Chapman in Local Government and State Aid, p. 91. If a borough can have a whole policeman for the cost of half a policeman it will be likely to have more policemen than it is really worth while to have, just as, if somebody offered to pay half the cost of our beef and not half the cost of our mutton we should increase our consumption of beef. It would appear then that this payment might well be swept away and the whole cost of police localised on the police authority's area.

The next financial relation to consider is that which exists between the unions on the one hand and the county boroughs and administrative counties on the other. The unions are entitled to draw from the counties and county boroughs in which they are situated:

(1) Certain sums for teachers in poor law schools, school fees for pauper children attending public elementary schools, and a portion of the remuneration of registrars of births and deaths.

(2) An amount equal to the salaries, superannuation and allowances of union officers, and the cost of drugs and medical appliances, not in the current or preceding year, but for 1887-8.

(3) Four shillings a week for each pauper lunatic maintained in an asylum.

In Table II. I have worked out the results of these payments in Lancashire. 


\section{TABLE II.}

Amount in the $£$ of rateable value received by each union in Lancashire from the county and county boroughs, 1899-1900.

(1) Unions wholly within the administrative county:

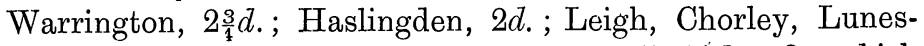
dale and Ulverston, $1 \frac{3}{4} d$.; Barton on Irwell, $1 \frac{1}{2} d$. ; Ormskirk and Lancaster, $1 \frac{1}{4} d$. ; Garstang, 1d.; Fylde, $\frac{3}{4} d$.

(2) Unions partly in the administrative county and partly in county boroughs :-

Salford, $3 \frac{1}{4} d$. ; West Derby and Chorlton, 3d.; Rochdale,

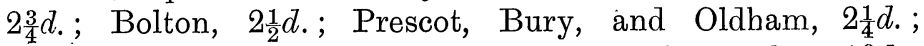

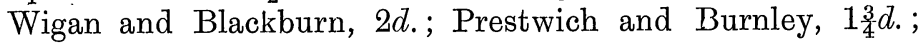
Preston, $1 d$.

(3) Unions consisting only of parts of county boroughs:Liverpool and Manchester, $3 \frac{1}{2} d$. ; Toxteth Park, $2 \frac{3}{4} d$.

(4) Union conterminous with a county borough :Barrow-in-Furness, $1 \frac{3}{4} d$.

(5) Unions partly in the administrative county and partly in other counties :-

Ashton-under-Lyne, $2 \frac{1}{4} d_{\text {. }}$; Clitheroe, $2 d$.

It will be seen that the relief only varies from $1 d$. to $3 \frac{1}{2} d$., but even this gives an exaggerated idea of the difference actually made by the payments, since the highest and lowest payments are not within the same county or county borough area. It obviously makes no difference to the ratepayers of the union of Preston whether the ratepayers of Liverpool and Manchester unions receive $3 \frac{1}{2} d$. or a shilling in the $£$, since the sum, whatever it is, will be paid by the county boroughs of Liverpool and Manchester. So, too, as only a portion of the union of Preston and a very small portion of the union of Salford are in the administrative county, the $3 \frac{1}{4} d$. of Salford is of only the most infinitesimal importance to Preston. The extreme of variation seems to be really between the $2 \frac{3}{4} d$. of Warrington and the $\frac{3}{4} d$. of Fylde, since both these contributions came wholly from the administrative county. Since the date of these returns however, Warrington has become a county borough, so that it is now probably true to say that these payments from the county boroughs to the unions do not make a penny in the $\&$ of difference in any part of Lancashire. In places where the union is conterminous with the county borough they make no difference at all, and the present tendency is for the great towns to rearrange boundaries so as to secure this identity of areas. 
The question therefore arises whether, supposing the alterations in the burden of pauperism effected by the system were exactly just or expedient in themselves, it would be worth while to maintain the system at the cost of all the complication and obscurity of accounts which it occasions. As I have said already, the first requisite of public finance is simplicity, and simplicity is cheap at $1 d$. in the pound.

But I do not think anyone will contend that the trifling redistribution of burden is by any means an ideal distribution. It may perhaps be right that Fylde, which includes Blackpool, should get so little, but can it be right that Garstang or Lancaster should have had so much less than Lunesdale or Ulverston, and that Warrington should have had $\frac{3}{4} d$. more than Haslingden? Let us consider the payments in detail. Those for school teachers, school fees, and registrars only amount to $£ 50,000$ in all England and Wales, and as this sum is widely spread over the unions it can scarcely make more than an infinitesimal difference in any particular county or union. The payments of the sums equal to the union officers' salaries and cost of drugs and medical appliances in 1887-8 obviously favour stationary and declining unions at the expense of growing ones. Surely nothing can be more absurd than a system of fixed payments like this. It owes its origin to a stupid amendment introduced by the House of Commons into the Local Government Bill providing that no borough should be placed in a worse position than it then occupied. The Local Government Act Commissioners thought this could only be safely secured by providing that each borough should begin by having all that it had before. The payments for pauper lunatics do slightly spread the burden of lunacy wherever the paying area is larger than the union, but this result might be obtained much more completely and much more satisfactorily in a much simpler way. At present the counties and county boroughs which build, pay for, and manage the asylums pay a fixed sum (4s. a week) towards the maintenance of lunatics in these asylums, while the unions, which have no control whatever over the management of the asylums and the expenditure upon the lunatics, pay the remainder of the cost, whatever the county or county borough may choose to make it. Obviously the proper arrangement is for the counties or county boroughs to pay the whole charge for the lunatics under their management.

The third financial relation with which we have to deal is that which is established between the administrative county 
and any county boroughs which are allotted to it by geographical situation and the Local Government Act. The administrative county has to divide with these county boroughs :-

(1) The aggregate proceeds of certain licence duties collected within the total area (administrative county and county boroughs).

(2) The share of certain other taxes collected within the United Kingdom which is allotted to it and its county boroughs, jointly by the State.

The general rule for this division is that the administrative county and each county borough first draw fixed amounts equal to, (1) the sum of the amount paid from the exchequer in 1887-8, towards the expenses of their areas in respect of the salaries of medical officers and sanitary inspectors, main roads, pay and clothing of police, poor law school teachers and medical officers, pauper lunatics, criminal prosecutions, vaccinators and registrars, and, (2) the cost of union officers in the same year. The remainder is then divided between the parties in proportion to their rateable value at the last periodical readjustment.

On the average, as between the counties and county boroughs, this division is very nearly in proportion to rateable value. The counties get just $9 d$. in the $£$ of rateable value and the boroughs a very little less. But in particular counties the division is often far from being in proportion to rateable value, and is therefore of more immediate financial importance than any of the payments we have yet considered except those for urban main roads. In Table III. the effect of the division is worked out in three very dissimilar counties. It will be seen that in Lancashire and Glamorganshire there is a variation of $4 d$. in the $£$ and in Oxfordshire one of $3 \frac{3}{4} d$.

\section{TABLE III.}

Amount in the $\&$ of rateable value taken by the administrative county, and each county borough from the sum of licences, estate duty, and "whisky money" belonging to the whole county in 1899- -1900 .

(1) In Lancashire :-

Administrative county, $7 \frac{1}{2} d$.

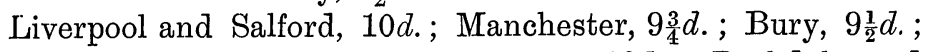
Oldham and Wigan, $9 d$.; Preston, $8 \frac{3}{4} d$. ; Rochdale and Barrow, $8 \frac{1}{2} d_{\text {. ; }}$ Blackburn and St. Helen's, $7 \frac{1}{2} d_{\text {. }}$; Bootle, $7 d$. ; Burnley, $6 \frac{1}{2} d$. ; Bolton, $6 d$. 
(2) In Glamorganshire :-

Administrative county, $7 d$.

Swansea, 10d.; Cardiff, $6 d$.

(3) In Oxfordshire:-

Administrative county, $1 s .0 \frac{3}{4} d$.

Oxford, $9 d$.

The general 'effect of the distribution is a little difficult to follow. In the first place the parties which had the highest grants and highest cost of union officers in 1887-8 are favoured by the allocation of the fixed sums equal to these amounts. But this inequality may be either aggravated or diminished by the subsequent alterations in the relative rateable value of the parties. If theadministrative county or the county borough received a large amount in proportion to its rateable value in 1888 , but has since increased in rateable value faster than its partners, its advantage will have diminished, and vice versâ. On the other hand, in the division of the remainder, increase in relative rateable value brings about an increase in the proportion of the total obtained by a partner. And, finally, as the remainder grows while the fixed sums remain constant, the distribution of 1887-8 plays, as time goes on, a less and less important part in the division of the total.

The objections to this financial relation are tolerably obvious. It is absurd so far as it is based on the distribution of 1887-8, and it is nugatory so far as it is based on present rateable value. The very object of having these financial relations is to make some difference to the relative rates of the different localities. A distribution according to rateable value between two areas simply makes those areas one for that purpose.

The last financial relation we have to consider is that which exists between the sixty-two areas formed by adding to each administrative county the county boroughs allotted to it by geographical situation and the Local Government Act. This arises from the fact that these areas divide among them in certain proportions a certain total, namely a particular part of the annual produce of the estate duty, amounting at present to about two millions, and a particular part of the produce of customs and excise duties amounting at present to nearly a million. This is obviously entirely different from cases where an area receives from the state a sum, such as the licences collected within the area, which may increase or diminish according to local circumstances without increasing or diminishing the shares of other localities. 
The total is divided between the sixty-two administrative counties each with its included county boroughs (if any) in the same proportion as certain grants amounting in all to $£ 2,860,384$ were divided between the same areas in the year 1887-8. These proportions can be found with some trouble by adding together the amounts opposite the administrative counties and their county boroughs in the annual return which bears the very unenlightening title "Local Taxation (England) Account." As the amount of the Estate duty grant and the Customs and Excise grant together at present just about equal the " discontinued" grants I have taken the amount of the discontinued grants applicable to each area, and worked it out in pence in the pound on rateable value, and then arranged the counties in the order in which they are favoured in Table IV., while Table V. shows the amount per inhabitant in the same way.

TABLE IV.

Amount in the $£$ (on the valuation of $1899-1900$ ) of " the discontinued grants" in each administrative county with its county boroughs.

Wilts, $6 d$.

Dorset, $5 \frac{1}{4} d$.

Hereford, Montgomery, $5 d$.

Middlesex, Oxford, Isle of Wight, $4 \frac{3}{4} d$.

Kent, Essex, Gloucester, Norfolk, Bucks, Denbigh, Huntingdon, Isle of Ely, $4 \frac{1}{2} d$.

Warwick, 'Somerset, Worcester, Northants, Berks, Herts, Cornwall, Beds, Cambs, Brecon, $4 \frac{1}{4} d$.

London, Lancs, Staffs, Surrey, Parts of Kesteven, Flint, Soke of Peterborough, $4 d$.

Devon, Derby, Notts, Salop, Monmouth, Cardigan, $3 \frac{3}{4} d$.

W.est Riding, Cheshire, Hants, East Sussex, Leicester, Parts of

Lindsey, East Suffolk, West Sussex, Carnarvon, Carmarthen, Rutland, Radnor, $3 \frac{1}{2} d$.

Durham, Northumberland, Cumberland, West Suffolk, Pembroke, Merioneth, $3 \frac{1}{4} d$.

East Riding, North Riding, Anglesey, $3 d$.

Westmoreland, $2 \frac{3}{4} d$.

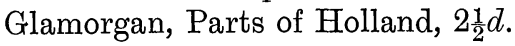

[Note.-To get the amounts received from estate duty and "whisky-

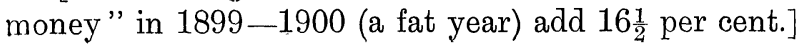




\section{TABLE V.}

Amount per inhabitant (census of 1901) of the "discontinued grants" in each administrative county with its county boroughs.

Hereford, 3s. 3ct.

London, Huntingdon, Rutland, 2s. 9d.

Montgomery, 2s. $8 d$.

Wilts, $2 s .7 d$.

Isle of Ely, Parts of Kesteven, 2s. 5d.

Dorset, Somerset, Oxford, $2 s$. $4 d$.

Radnor, $2 s .3 d$.

Isle of Wight, $2 s .2 d$.

Surrey, Cambridge, Salop, Bucks, 2s. $1 d$.

Middlesex, 2s.

Berks, Parts of Holland, Gloucester, Westmoreland, Beds, Flint, Herts, 1 s. $11 d$.

Cardigan, Brecon, Eäst Sussex, Kent, 1s. 10d.

Norfolk, West Sussex, 1s. 9d.

Northants, Soke of Peterborough, Parts of Lindsey, Devon, Cumberland, Cheshire, $1 s .8 d$.

Denbigh, Worcester, Warwick, $1 s .7 d$.

East Riding, Merioneth, Lancashire, Essex, 1s. 6d.

Cornwall, Monmouth, $1 s$. $5 d$.

West Suffolk, Northumberland, Notts, North Riding, East Suffolk, Derby, Hants, Carmarthen, Leicester, $1 s .4 d$.

Carnarvon, Pembroke, West Riding, Stafford, $1 s .32 d$.

Durham, $1 s$.

Anglesey, Glamorgan, $11 d$.

[Note.-To get the amounts received from Estate duty and " whisky money" in 1900-1, add 5 per cent.]

It will be seen that in regard to rateable value, while the very rural counties of Wilts, Dorset, Hereford, and Montgomery come off best, the equally rural county of the Parts of Holland is at the bottom, and Anglesey nearly at the bottom of the scale. There does not appear to be much to be made of a comparison of urban and rural counties. Geographically there would appear to be some truth in the statement that the north-east of England is worse treated than the south-west, and this is true with regard to the comparison by population as well as in regard to the comparison by rateable value.

There are, of course, two factors in the present distribution, (1) the relative share in 1887-8 compared with rateable value and No. 49.-VOL. XIII. 
population, and (2) the subsequent comparative growth of rateable value and population. Counties which were economical and consequently had small grants in 1887-8 and have since grown find themselves low down in the scale. Counties which were extravagant in 1887-8 or which have since diminished in value and population are high in the scale. Where the two appropriate characteristics for being high or low in the scale are combined the effect, of course, is considerable. We need no further explanation why Wiltshire is at the top and Glamorgan at the bottom.

Of this financial relation it may be said very shortly that it was obviously indefensible in 1881, and has become less and less defensible every year since then. It was only proposed as a temporary measure, and has been retained simply owing to the growing incompetence and unwillingness of Parliament to attend to the business of the country. So far as I know nobody has ever defended it. That it has not been more attacked than it has, is owing to the general ignorance which prevails as to its existence. There are many people who think the old grants are still given. A very few years ago a distinguished Manchester alderman of long standing thought so, and in advocating a reduction of the number of Manchester police, only claimed that Manchester would save half the cost of the pay and clothing; the other half he supposed would be gained by the exchequer.

Both of these last financial relations might, of course, be got rid of by the simple process of diverting the three and a half millions of licences and the three millions of estate duty and customs and excise to other purposes. Something has indeed already been done in this way: compensation for slaughtered cattle and also the rates which are paid for clerical tithe rent charge owners are already deducted from the original amount. Future Chancellors of the Exchequer, if they are wise, will keep on nibbling till nothing is left. If, however, the present great subvention is to continue, some new principle of distribution will have to be found for it. Lord Balfour of Burleigh has propounded with the approval of some of his colleagues on the Local Taxation Commission an elaborate and well devised plan for the distribution of grants. It is doubtful, however, whether it is simple enough, and it is highly probable that it would lead to census falsification. I am inclined to think that a much simpler solution would be more satisfactory:-

(1) Let the three and a half millions of licences be paid simply to the administrative counties and county boroughs in which they 
are collected without any " adjustment." This is already done as regards all the counties, including London, which do not happen to contain a county borough, and several other counties which have made agreements to that effect with their county boroughs. To make the practice universal would cause no injustice and would be immensely convenient. It would be easy to suggest taxes or portions of taxes much more suitable for allocation to local authorities than the licences, but this does not come within the limits laid down by the title of this article.

(2) Let the three millions arising from estate duty and customs and excise be distributed between the counties and county boroughs in proportion to the number of elementary school children in attendance. No better criterion of the need of a locality for help from the whole country can be found than the number of children it has in public elementary schools.

Edwin Cannan 